\title{
A Diamond in the Rough: Adjunct Faculty Opportunities and Challenges in Higher Learning Institutions
}

\author{
Albertus Barnes \\ Rasmussen University \\ Elisa Fredericks \\ Northern Illinois University
}

\begin{abstract}
The focus of this qualitative study was to interview a purposeful sample of adjunct faculty in higher learning institutions utilizing open-ended questions, which allowed the researchers to probe and explore selected participants' lived experiences and perspectives relating to factors affecting decisions to remain or leave higher learning institutions. Six final themes emerged regarding such factors, including (a) career direction, (b) number of students in the class, (c) satisfaction with the college, (d) enjoyment of higher education, (e) work for a servant leader, and (f) leadership style of the boss.
\end{abstract}

\section{BACKGROUND}

The retention of adjunct professors is essential to higher learning institutions (HLI) as high levels of retention contribute to institution effectiveness (Betts \& Sikorski, 2008; Bockerman \& Ilmakunnas, 2012; Caruth \& Caruth, 2013; Elder \& Ryan, 2016; Zinsser, 2017). Higher retention may positively influence the institution's reputation (Amos et al., 2015; Syed \& Yan, 2012) and promote positive learning for students. Research suggests when professors are satisfied with their job, leadership, and the institution itself, a positive learning environment is enhanced (AAUP, 2018, 2019; Al-Smadi \& Qbian, 2015; Caruth \& Caruth, 2013). Low levels of satisfaction among adjunct faculty result in higher levels of turnover and lead to lower levels of institutional effectiveness through higher costs to hire and train new adjunct professors (Barnett, 2017; Bockerman \& Ilmakunnas, 2012; Caruth \& Caruth, 2013; Kuvakas, 2018).

The topic of adjunct professor retention and the factors influencing job satisfaction is relevant today (Al-Smadi \& Qbian, 2015) as adjunct faculty are in high demand. Growth in numbers at both private and public institutions has been increasing steadily since 1975 (AAUP, 2018; GAO, 2018) from 24\% to 40\% of the labor force as of 2015. They now outnumber tenured faculty almost 2:1.

Adjunct faculty are critical to the operations of many HLI, and their retention is equally important. Effectiveness relates to goal and task attainment, the ability to exploit the environment, as well as leadership ability to mobilize for action (Mott, 1972). Through high quality, high quantity, information-seeking initiatives, and inventiveness, HLI can increase effectiveness and efficiency. When faced with change and challenges, resilient responses include coping, accepting, adjusting, and doing so quickly and appropriately with flexibility and adaptability (Guthrie, 2019; Hoy, 2009). Research suggests adjunct faculty may be one factor in alleviating these challenges. 
Researchers have aligned job satisfaction with retention of adjunct faculty (Caruth \& Caruth, 2013; Kuvakas, 2018), but little research exists elaborating on factors that increase and reduce job satisfaction for adjunct faculty. A few studies identified a link between job satisfaction, retention, and university effectiveness (Bockerman \& Ilmakunnas, 2012; Caruth \& Caruth, 2013; Rich, 2015). It is recognized that faculty costs (e.g., financial compensation) for adjunct faculty are significantly lower than that of tenured faculty (AAUP, 2013, 2018; GAO, 2018). Utilizing adjunct faculty is becoming a widely used cost-saving measure. The TIAA Institute (2016b) reported part-time adjunct workers to earn $64 \%$ less per hour than tenured or tenure-track counterparts.

\section{RESEARCH QUESTION}

The overarching research question was to determine which factors positively or negatively affect the satisfaction and retention of adjunct faculty in HLI. More succinctly, the research questions posed for this study were:

\section{RQ1: What institutional factors influence the satisfaction and retention of adjunct faculty?}

RQ2: What faculty level factors influence the satisfaction and retention of adjunct faculty.

\section{ADJUNCT FACULTY}

\section{Definition}

As of 2019 , adjunct faculty represented about $76 \%$ of faculty among all HLI in the U.S, up from the 2018 figure of $73 \%$ of all faculty positions (AAUP, 2018, 2019). Full-time tenure-track positions approximated 436,403; full-time adjunct positions 331,313, and part-time adjunct positions at 767,565 (GAO, 2018). The AAUP (2018) defined adjunct faculty as non-tenured, part-time adjunct professors and faculty with yearly contracts, working on a course basis, without any true job security or benefits. Many are legally considered at-will-employees (AAUP, 2019; Elder \& Ryan, 2016; GAO, 2018). The retention of adjunct faculty is also essential as they provide highly qualified, experienced faculty supporting the achievement of student learning outcomes, enhancement of student success, and an overall positive student experience (AAUP, 2018; Caruth \& Caruth, 2013, Kuvakas, 2018).

Adjunct part-time and full-time faculty typically represent at least $40 \%$ or more of university faculty (Blumenstyk, 2015; Haynie, 2012), but similar statistics vary greatly depending on whether the institution is private or public, or if the institution offers only 2- and 4-year associates (such as community colleges) and bachelor programs or if they offer all levels of secondary education up to and including doctoral programs (AAUP, 2018). Additionally, an increasing number of universities are replacing some of their full-time, tenured faculty with full-time adjunct faculty (AAUP, 2018; Eagan et al., 2015; Miller, 2018; Zinsser, 2017) for their seminal-degreed masters and doctorate programs.

In many community colleges, including 2- and 4-year degreed institutions, adjunct faculty teach undergraduate courses (Curtis \& Thornton, 2013). The AAUP (2018) reported the highest utilization of adjunct faculty at 2-year institutions $(65 \%)$. At research-intensive learning institutions, tenured and tenuredtrack faculty comprise about $35 \%$ of all faculty; at 2-year institutions, these same faculties comprise about $20 \%$ of all faculty (AAUP, 2019).

The topic of institutional effectiveness has received considerable interest from professional educators and business administration scholars (Abrahamson, Berkowitz, \& Dumez, 2016; Larsson, Magnusson, \& Ullenhag, 2014) and its relationship to the retention of adjunct faculty at HLI (Caruth \& Caruth, 2013; Kuvakas, 2018). Safeguarding and retaining a competitive edge in the U.S. regarding quality education is essential (House Committee on Education and the Workforce, 2015; Johnson, 2015). 


\section{Compensation and Benefits}

Several issues of concern relating to retaining highly qualified and needed adjunct faculty in HLI to exist, given their predicted increased usage and reduction in availability due to possible retirement (Christensen, 2008; House Committee on Education and the Workforce, 2015; Johnson, 2015; Pearch \& Marutz, 2005). If such predictions hold true, a reduction in available adjunct faculty is troublesome given their increasing usage. Job challenges, salaries, and benefits affect job satisfaction among adjunct faculty, which in turn affect retention (Barnett, 2017; Chong \& Monroe, 2013).

Tenured and tenured-track faculty salaries typically "range from $\$ 60,000$ to $\$ 100,000$ per year, whereas the average annual salary of full-time adjunct faculty is $\$ 57,500 "$ (TIAA Institute, 2016b, p. 1). Furthermore, adjunct faculty rarely receive university-paid benefits (e.g., health insurance, pension plans), whereas university-paid benefits are nearly always part of tenured faculty contracts (AAUP, 2018; GAO, 2018; Murray, 2019). The relatively low costs for HLI associated with the utilization of adjunct faculty are the driving force behind their increasing usage (Curtis \& Thornton, 2013; Fabricant, 2014; Kuvakas, 2018; Shayne, 2019; TIAA Institute, 2016a, 2016b).

Researchers maintain that job challenges, salaries, and benefits are significant concerns for adjunct faculty (Barnett, 2017; Chong \& Monroe, 2013; Lewin, 2013); low salaries and the lack of benefits are the most significant challenges for adjunct faculty (Kuvakas, 2018). The provisions in the Affordable Care Act (ACA; Adjunct Action/SEIU, 2014) provided adjuncts with possible eligibility for health benefits; however, universities can circumvent these provisions through job descriptions that do not include hours outside of the classroom (thereby ineligible under the ACA). Stipulations in the ACA do not cover adjuncts if employment agreements require adjuncts to accept contract employment without benefits (AAUP, 2013; House Committee on Education and the Workforce, 2015; Marlier, 2014; Moran, 2014). Universities can also avoid providing benefits by limiting the number of courses offered to adjunct faculty.

Administrators in HLI need to utilize resources effectively and efficiently (Hoy, 2009; Hoy \& Ferguson, 1985; Powell, Gilleland, \& Pearson, 2012). An increasing number of university managers are offering professional development to adjunct professors. The results have been overall positive, with adjunct faculty reporting feeling valued, respected, and better trained in the university mission as well as their jobs (Bedford \& Miller, 2013). University leaders also need to ensure fair compensation for adjunct faculty compared to work and workloads as well as allowing for work and life balance. Higher education managers need to help the adjunct population integrate more with the university through increased communication efforts (Hoeller, 2014; Zinsser, 2017). It is critical that administrators implement programs and methods which ensure the retention of this valuable workforce due to the financial advantages provided (Betts \& Sikorski, 2008; Caruth \& Caruth, 2013; Kuvakas, 2018; Zinsser, 2017).

\section{STUDY PURPOSE}

The purpose of this qualitative, phenomenological study was to identify factors that influence the satisfaction and retention of adjunct faculty in HLI. A qualitative study should have a sample size between 5 and 25 participants or until the data becomes saturated (Charmaz, 2006; Creswell \& Creswell, 2018). The study population included ten adjunct faculty responding to 8 research questions.

VanScoy and Evenstad (2015, p.332) indicated when the focal point is the study of human experiences, a phenomenological analysis method emerges as an excellent method of investigation (p. 338). The conceptual framework of this study suggests factors exist affecting the retention of adjunct faculty in HLI. At the institutional level, factors include the reputation of the institution and the leadership style of its leaders (Amzat \& Idris, 2012; Barnett, 2017; Chong \& Monroe, 2013). Factors at the faculty level consist of job satisfaction, job challenges, salary, and benefits (Amzat \& Idris, 2012; Barnett, 2017; Chong \& Monroe, 2013). 


\section{ORGANIZING FRAMEWORK}

Interestingly, a link exists between job satisfaction for adjunct faculty and the leadership styles of university leaders (Amzat \& Idris, 2012; Bayram \& Dinc, 2015; Omar \& Hussin, 2013). However, the link between leadership styles is not defined clearly or completely understood (Samad, 2016). Walters (2015) investigated adjunct faculty satisfaction, retention in higher education, and leadership practices and determined uncertainty exists as to why adjuncts were happier if leaders demonstrated servant leadership styles as opposed to transformational, transactional, or laissez-faire styles. Leadership styles in HLI should demonstrate highly effective communication skills, empathetic qualities (Razak \& Hamidon, 2015), empowering others (Anderson, 2017), and the willingness to share knowledge (Asmawi, Zakaria, \& Wei, 2013).

Higher learning environments are unique, and no one leadership style may align optimally with missions, influences, and challenges (Dias \& Borges, 2017; Hauserman \& Stick, 2013; Khan, 2017; Perry, 2000; Smith, 2015). Research suggests a blended leadership style may offer the best leadership quality in the workplace and affect retention, job satisfaction, and student success (Hauserman \& Stick, 2013; Lamm, Lamm, Rodriguez, \& Owens, 2016). This research sought to investigate whether leadership style is one factor influencing job satisfaction and retention of adjunct faculty. Leadership Theory provides a lens through which such association can be viewed.

\section{Leadership Theory}

Institution effectiveness is reliant upon leadership that achieves an environment where it can attain resiliency when faced with change and challenges. Most important, leadership style must be flexible and well suited for the institution (Bass, 1990; Lamm et al., 2016). Leadership theory has begun to realize leadership is active and participative, involves motivating followers, and is inseparable from followers' needs and goals (Bass, 1990; Kupers, 2007). It may be a key influencer as to why employees remain at their job. According to Kouzes and Posner (2002), "People, in fact, don't generally quit companies, they quit managers" (p. 283). In the educational world, instructors are more likely to quit because of problems with direct reports, administrative leaders rather than the institution. HLI must exploit the environment, react efficiently and effectively when faced with a change to ensure retention of adjunct faculty (Elder \& Ryan, 2016; Guthrie, 2019; Hoy, 2009; Mott, 1972). Leadership style itself is not as important as is its effectiveness, appropriateness, and responsiveness to the needs of all stakeholders. Some types of leadership may have a larger influence on the institution and its daily activities. Other types of leadership have very little, if any, regarding daily activities. Bass and Avolio (2008) identified three predominant leadership styles: transformational, transactional, and laissez-faire. Servant leadership is included due to its emergence style applicable during the 21 century (Parris \& Peachey, 2013; Sherman, 2019). A review of each one follows.

\section{Transformational Leadership Style}

As an active leadership style, transformational leaders inspire and build confidence in subordinates which leads to improved operational success (Daft, 2008; Anderson, 2017). Four dimensions characterize transformational leadership; (a) idealized influence, (b) inspiration, (c) intellectual stimulation, and (d) individualized consideration (Avolio \& Bass, 2004; Bass \& Avolio, 2008). Idealized influence translates to charisma. It involves a process through which a leader instills organizational subordinates with leader vision and a sense of mission for the organization. This approach builds respect, trust, and confidence (Barrick et al., 2015; Moynihan, Pandey, \& Wright, 2012; Olsen, Eid, \& Larsson, 2010; Pandey, Wright, \& Moynihan, 2012).

Transformational leaders employ the process of inspiration as a means of increasing optimism and enthusiasm and create a heightened sense of awareness among subordinates about problems requiring solutions for the organization to succeed (Konorti \& Eng, 2008). One way to attain this outcome is by providing organizational subordinates intellectual stimulation, encouraging a different and better perspective within which to view problems (Moynihan et al., 2012). The process of individualized 
consideration encompasses providing support, encouragement, and developmental experiences for organizational subordinates (Barrick et al., 2015; Moynihan et al., 2012; Olsen et al., 2010; Pandey et al., 2012). These leadership outcomes are also crucial in organizations that are in a transformational stage of development (Gill, Sharma, Mathur, \& Bhutani, 2012; Kaplan et al., 2010; Klenke, 2007; Kuipers et al., 2014; Küpers, 2007).

Leader style is directly related to institutional effectiveness. Transformational leadership is most often associated with high levels of effectiveness in both non-profit and for-profit organizations (Anderson, 2017; Bass, 1990; Bass \& Riggio, 2006; Hauserman \& Stick, 2013; Hijazi, Kasim, \& Saud, 2016). At HLI, transformational leadership has proven effective (Anderson, 2017; Bateh \& Heyliger, 2014; Francis, 2017). Additionally, it can lead to increased job satisfaction and performance in adjunct faculty (Bayram \& Dinc, 2015; Sakiru et al., 2014; Thamrin, 2012). Bass et al. (2008) noted transformational leadership uses leadership by example to foster a trusting cultural environment others willingly follow. In HLI specifically, transformational leadership styles increase efficiency and efforts, thereby creating higher levels of follower satisfaction, empowerment, and the meeting of needs (Barnett, 2017; Bass, 1990; Francis, 2017). Northouse (2013) noted the components of high ethics and morals make a difference, particularly in higher learning environments. Other researchers suggest the leadership style most appropriate for dealing with adversity in organizations is transformational (Avolio \& Bass, 2004; Bass, 1990; Bass \& Avolio, 2008; Bateman \& Snell, 2009; Kupers, 2007).

\section{Transactional Leadership Style}

Transactional leadership style pursues a cost-benefit, economic exchange to meet the needs of organizational subordinates in return for services provided (Bass \& Avolio, 1994). Transactional leaders use extrinsic motivators very effectively, such as offering promises or rewards for appropriate levels of effort and responding to employee self-interest as long as they are getting the job done (Francis, 2017).

This cost-benefit exchange exists even in organizations with transformational leaders. The difference being in organizations with transformational leaders, the primary motivation is not necessarily the costbenefit relationship between the organization and the employees. Rather, transformational leaders motivate organizational subordinated to act in the pursuit of the vision the leader has instilled throughout the organization (Barrick et al., 2015; Moynihan et al., 2012; Olsen et al., 2010; Pandey et al., 2012).

Bass (1994) defined a transactional leader as one who recognizes follower needs, recalls how vital identifying needs are to motivation, and tries to see that the organization satisfies those needs if employee performance warrants it (Bass et al., 2003). In higher learning environments, leadership studies have shown mixed results regarding which style is most effective (Khan, 2017). Aydin, Sarier, and Uysal (2013) found a positive effect on professor job satisfaction under transactional leadership. Transformational leadership did not have as strong an effect. Barnett (2017) summarized findings in global countries concluding transactional leadership as highly effective in higher learning environments, showing positive correlations with job satisfaction in Nigeria (Francis, 2017; Sakiru et al., 2014) and the United States (Bateh \& Heyliger, 2014), and employee motivation in Pakistan (Chaudhry \& Javed, 2012). Job satisfaction is critically important to HLI effectiveness and performance (Amos et al., 2015; Pan et al., 2015) as it requires monitoring by the administration to ensure adjunct faculty satisfaction (Al-Smadi \& Qbian, 2015).

In this study, university-level factors are believed to influence adjunct faculty satisfaction and retention. Based on the foregoing discussion, the following propositions are presented:

P1: A leader's (e.g., dean, chairs, and managers) leadership style affects satisfaction and retention of adjunct faculty.

P2: Transformational leadership will be positively related to adjunct faculty satisfaction and retention.

P3: Transactional will be positively related to adjunct faculty satisfaction and retention. 


\section{Laissez-Faire}

Laissez-faire leadership is very passive, one who avoids decision-making and supervisory responsibility (Sharma \& Singh, 2013). The laissez-faire leader is inactive rather than being reactive or proactive (Deluga, 1990; Sharma \& Singh, 2013). Very passive leadership has been found to align negatively with more active leadership styles, such a transformational leadership and transactional leadership (Bass, 1990). Further, there is a negative association between very passive leadership and subordinate performance, effort, and attitudinal. Thus, active leadership styles, such as transformational and transactional, are preferred in most instances over very passive leadership styles (Glew, O'Leary-Kelly, Griffin, \& Van Fleet, 1995). Trottier et al. (2008) found that laissez-faire leadership and transactional leadership "constitute the basis of the leadership function, while higher-level factors - transformational leadership - constitute advanced or high-performing leadership" (p. 321). However, the gig economy may have shifted satisfaction and retention priorities as adjunct faculty may seek financial wellbeing over other satisfaction variables (Gesemia. Monson \& Adibifar, 2020).

\section{Servant Leadership}

Servant leadership emphasizes the importance of having an attitude of service to and for others, mentoring, and putting others first for the betterment of the organization (Chen, Zhu, \& Zhou, 2015; Sherman, 2019). Servant leaders are humble, caring, trusting, demonstrate unconditional love, live to serve others first, and value others (Focht \& Ponton, 2015; Greenleaf, 1977; Parris \& Peachey, 2013; Sherman, 2019; Van Wart, 2013).

Research espouses servant leadership as the type of leadership needed in the 21 st century to address challenges posed to organizations (Parris \& Peachey, 2013; Sherman, 2019). However, in HLI, researchers have struggled to find the applicability of servant leadership (Focht \& Ponton, 2015). Servant leadership shares some of the traits of transformational leadership; both styles focus on empowering and mentoring others for the success of the organization (Choudhary, Akhtar, \& Zaheer, 2013), but each use unique means by which to achieve these outcomes (Van Dierendonck, Stam, Boersma, De Windt, \& Alkema, 2015). In stable HLI, servant leadership might prove optimal; however, if the institution is facing or undergoing change, transformational leadership is likely to be more effective (Smith, Montango, \& Kuzmenko, 2004; Van Dierendonck et al., 2015). Both servant and transformational leadership positively affect organizational performance and job satisfaction (Alonderiene \& Majauskaite, 2016; McNeff \& Irving, 2017; Song, Park, \& Kang, 2015). Leadership styles can affect the performance of leaders in efforts to overcome organizational change.

Based on the preceding discussion on leadership theory and the importance of adjunct faculty satisfaction and retention, the following propositions are presented:

\section{P4: Laissez-faire leadership will be negatively related to adjunct faculty satisfaction and retention.}

\section{P5: Servant leadership will be positively related to adjunct faculty satisfaction and retention.}

Kuvakas (2018) notes, adjunct faculty do not teach for financial gain but rather aspire to be part of a community, share professional knowledge, and work with students. Most adjuncts are not interested in professional growth; however, faculty expressed concern about the connection between academic freedom and the evaluation of their work by students (Kuvakas, 2018). Researchers agree higher retention may positively influence the institution's reputation (Amos et al., 2015; Syed \& Yan, 2012.). Previous research links adjunct faculty job satisfaction with inclusion in university, college, and department initiations even though participation is not always required.

Based on the discussion above, the following propositions are presented:

P6: Participation in university and college initiatives will be positively associated with adjunct faculty retention. 
P7: Adjunct faculty job satisfaction with be positively associated with enhanced relationships with faculty and students.

P8: Participation in university and college initiatives will be positively associated with high-quality teaching among adjunct faculty.

P9: Professional growth will not be associated with adjunct faculty retention.

P10: The reputation of higher learning institutions will have no effect on adjunct faculty satisfaction and retention.

Rich (2015) noted little research has focused on adjunct faculty job satisfaction. When adjunct faculty are highly satisfied, they tend to be more committed to the university and the job itself; they also tend to develop relationships with peers and deliver a high level of quality instruction to students (Amos et al., 2015; Syed \& Yan, 2012). Most adjunct faculty are not offered university-provided health benefits, their salaries are lower than that of full-time tenured faculty, and they experience less frequent communication with their learning institution (Hoeller, 2014, as cited in Zinsser, 2017). Job challenges for adjunct faculty include feeling satisfied with their jobs, working long hours, and achieving work/life balance (Barnett, 2017; Chong \& Monroe, 2013). In summary, adjunct faculty deal with challenges and obstacles which block feelings of value, respect, and inclusion in the university.

Based on the above discussion, the following propositions are presented:

\section{P11: Adjunct faculty salary affects satisfaction and retention.}

\section{P12: Adjunct faculty course load affects satisfaction and retention.}

\section{P13: Adjunct faculty benefits (or lack of benefits) influence satisfaction retention.}

The purpose of this research is to conduct exploratory research confirming or supplementing existing research on factors contributing to adjunct satisfaction and retention in HLI. Kuvakas, (2018) noted a dearth of research in this area.

\section{RESEARCH METHOD}

The study followed a qualitative methodology using a phenomenological design most appropriate when the researcher wants to hear and understand the experiences of a group of participants (Creswell and Creswell, 2018). Interpretative phenomenology seeks to understand the lived experiences to make meaning of those experiences. The researcher plays a central role through in-depth exploration to determine themes common to participants (Creswell \& Creswell, 2018; Leedy \& Ormrod, 2019; Smith, 2011) and to glean and make meaning of those experiences in order to gain a deeper understanding of the phenomenon. The population for this study was adjunct faculty at HLI. The suggested number of participants for qualitative, phenomenological studies using interviews to collect data is between 5 and 25 (Creswell \& Creswell, 2018; Smith \& Eatough, 2012), which enables the depth of the data to be purposeful, meaningful (Miles \& Huberman, 1994; Patten, 2012) and rich (Creswell \& Creswell, 2018; Maxwell, 1996).

The interview instrument contained semi-structured, open-ended questions with probes as needed. The research question guided the construction of the interview questions to capture the necessary information during the interviews. Zoom interviews were the closest alternative to face-to-face meetings and were the

preferred method for qualitative data collection. Inductive analysis is typical in qualitative studies, and this type of analysis is based on thematic identification (Creswell \& Creswell, 2018; Leedy \& Ormrod, 2019; Patten, 2012, Patton, 2002). Data collection and analysis were ongoing and cyclical in nature. As data were analyzed, other data were collected and scrutinized for relevance. The sample included experienced part- 
time teaching adjunct faculty with at least ten years of experience. The average experience of participants was 19.5 years from the five universities selected. The location of participants ranged across two time zones. The interviews focused on experiences in their current role at the university. The interview length was between 30 minutes to 1 hour and 10 minutes. Interview questions are provided below.

\section{TABLE 1 INTERVIEW QUESTIONS}

\begin{tabular}{|l|l|}
\hline Number & Question \\
\hline IQ $_{1}$ & $\begin{array}{l}\text { What are the main factors that might influence you to continue or not continue to work as } \\
\text { an adjunct professor in a higher learning institution? }\end{array}$ \\
\hline IQ $_{2}$ & $\begin{array}{l}\text { What tools and resources provided or not provided by the college or university do you } \\
\text { believe retain you in your job as an adjunct professor? }\end{array}$ \\
\hline IQ $_{3}$ & $\begin{array}{l}\text { What types of leadership styles do you prefer to help retain you in your role as an adjunct } \\
\text { professor? }\end{array}$ \\
\hline IQ $_{4}$ & $\begin{array}{l}\text { How would you describe the compensation and benefits best ensure you continue teaching } \\
\text { at your university? }\end{array}$ \\
\hline IQ $_{5}$ & $\begin{array}{l}\text { What do you consider job challenges that reduce the likelihood of you continuing as an } \\
\text { adjunct professor at your higher learning institution? }\end{array}$ \\
\hline $\mathrm{IQ}_{6}$ & $\begin{array}{l}\text { Based on your current teaching workload, please explain whether you believe the course } \\
\text { load is adequate and affects your decisions to remain/or leave your higher learning } \\
\text { institution? }\end{array}$ \\
\hline IQ $_{7}$ & $\begin{array}{l}\text { Please explain whether you are currently working in your field of study helps to retain you } \\
\text { in your role as an adjunct professor. }\end{array}$ \\
\hline IQ $_{8}$ & $\begin{array}{l}\text { What type(s) of leadership styles at the university best ensures your continued and } \\
\text { longtime service at the university? }\end{array}$ \\
\hline
\end{tabular}

During the data collection phase, the researcher was looking for key terms, patterns, and categories, a hallmark of phenomenological studies. Once the researcher absorbed all of the interviews, conducted initial coding, and moved into analyzing the emergent patterns, categories, phrases, or statements, themes emerged; many themes also had patterns to be. The themes and patterns help the researcher identify relationships between and within the data explored (Creswell \& Creswell, 2018; Leedy \& Ormond, 2019; McMillan \& Schumacher, 2019). Themes and relationships form the basis of the study findings.

\section{FINDINGS}

Once the interviews were complete, the digitally recorded files were sent to Rev.com for transcribing, and then NVivo was used to systematically organize the data from the transcripts during the first pass. During the second pass, the initial themes began to emerge. The last pass, the researcher synthesized the themes, and the final themes emerged: (a) career direction, (b) number of students in the class, (c) satisfaction with the college, (d) enjoyment of higher education, (e) work for a servant leader, (f) leadership styles of their boss. Participants shared knowledge based on their experiences in their roles as adjunct faculty. 


\section{TABLE 2}

\section{EMERGING RESEARCH THEMES}

\begin{tabular}{|l|l|}
\hline Final Study Themes & Number of Respondent Mentions \\
\hline Career Direction & 8 \\
\hline Number Students in the Class & 9 \\
\hline Satisfaction with the College & 10 \\
\hline Enjoyment with Higher Education & 9 \\
\hline Work for a Servant Leader & 8 \\
\hline Leadership Style of the Boss & 10 \\
\hline
\end{tabular}

*10 Participants responded to 8 questions. $\mathrm{R}$ indicates the respondent and reply.

\section{Final Theme 1: Career Direction}

The theme of career direction was mentioned several times in the transcript data analysis. It was implied in some cases. Career direction included adjunct professor satisfaction with current positions. This theme was not explicitly stated as a career direction. However, it was implied in the interview question by respondent 10. The participant said he was pleased with his current role, motivated to continue teaching, and would likely continue teaching in hopes of becoming a full-time professor as he is planning to start his doctoral journey in the near future. The following interview response is representative of this theme from the interview questions.

R10 - "On the first point, I enjoy the content, and I enjoy discussing those topics from a criminal justice perspective. From a practical perspective, security management is sort of an offshoot from the main criminal justice topic. So professionally, I also enjoyed the opportunity to develop future security leaders and craft security policies."

The theme of career direction did not align directly with research findings, does not support P9, and represents an area for future investigation.

\section{Final Theme 2: The Number of Students in the Class}

This theme was mentioned several times in the transcript data analysis. Respondent 8 said if there are too many students in her class, that is a disadvantage, and she would leave her institution because the workload would be too great. Respondent 9 suggested there are students who are not college-ready, and the university could do a better job of screening the applicants. Low levels of job satisfaction among adjunct faculty are related to job challenges, stress, long working hours, course overload, and feelings of isolation among adjunct faculty. The resultant impact is higher turnover rates (Amzat \& Idris, 2012; Barnett, 2017; Bholane \& Suryawanshi, 2015; Chong \& Monroe, 2013).

The following interview response is representative of this theme from the interview questions.

R8 - "I think now, with this virus, they're going to increase the load for the students, and I'm sorry for the faculty. We're normally around 25-30 students, and we get paid per class for 25-30. It seems like they want to take it to a hundred."

R9 - "Well, some of the challenges are some colleges don't screen the students and applicants with high regard as they should. Some of them let people in the college that are not really qualified to be in the programs or in graduate school."

This theme directly aligned with research findings and supports P12. 


\section{Final Theme 3: Satisfaction With the College}

The theme of satisfaction with the college entailed being satisfied with the administration-the college administration included deans, managers, and supervisors of adjunct faculty. The reputation of the college was mentioned once in the data analysis, and the participant said it is essential to retain him in his role as an adjunct faculty. As research indicates, job satisfaction of adjunct faculty primarily relates to challenges of the job itself as opposed to a commitment to the university, age, experience, or intrinsic factors (Amzat \& Idris, 2012; Barnett, 2017; Bholane \& Suryawanshi, 2015). Much affects the job satisfaction of adjunct faculty who are critically important to HLI institution effectiveness and performance (Amos et al., 2015; Pan et al., 2015). It also encompasses adjunct faculty satisfaction with the student-based population. The following interview response was representative of this theme from the interview questions.

R2 - "I enjoy working with the faculty and student-based population...the adjuncts mostly work with adult students returning to school."

The theme of satisfaction with the college did not align directly with research findings and represented areas for additional research. P10 reputation of the university was not supported and represented an additional research area.

\section{Final Theme 4: Enjoyment of Higher Education}

Enjoyment of higher education theme was mentioned or implied by all participants. Participant 4 stated she enjoys teaching. The fact that students are understanding the content and seeing students having an aha moment is most enjoyable. She said that as long as her students are having that aha moment, she will continue to remain in her current role as an adjunct. High levels of job satisfaction of adjunct faculty increase commitment to the job, the University, and quality student instruction, as well as low rates of turnover (Amos et al., 2015; Syed \& Yan, 2012). The retention of adjunct faculty is vital to a higher learning institution in that high levels of retention contribute to institutional effectiveness, positively influence the institution's reputation, and promote a positive learning environment for students because institution professors are satisfied with their job, leadership, and the institution itself(Caruth \& Caruth, 2013; Kuvakas, 2018).

The following interview response was representative of this theme from the interview questions.

R4 - "One motivating factor is when I see students have the aha moment. I say that because I teach a lot of legal courses, and with the legal courses, it is forever changing, always evolving, and forever moving."

The topic of compensation was mentioned several times, and the participants were mostly satisfied with their salaries.

R3 - "We get the pay: again, the pay is exceptional. When it comes to pay, especially if you teach a graduate course, I think it's fair."

R9 - "Well, the first thing that I always look at when I've been asked to do something for an institute of higher learning is their reputation."

R 10 - R9 - "Well, the compensation and benefits to me are not really important at this time in my life."

This theme did align with research findings and supported P 11 and 13. 


\section{Final Theme 5: Work for a Servant Leader}

The participants are referring to their deans, chairs, or supervisors and prefer to be managed by this type of leader. A servant leader demonstrates high ethical standards, emphasizes the importance of empowering others, developing trust, and enhancing the growth in others (Sherman, 2019). Work for a servant leader theme was mentioned directly and indirectly in the research study. Nevertheless, transformational, transactional, and servant leaders were mentioned the most. Respondents 5 and 10 stated servant leaders were their preferred types of leaders. Other participants implied servant leaders were their choice of leader.

The following interview response is representative of this theme from the interview questions.

R10 - "Definitely servant leadership, and collaborative leadership. Servant leadership in collaborative settings. A lot of my examples will involve my dean, but I think so much of him as a professor, and as a person that has been in law enforcement, has gotten his Doctorate Degree, and he's very passionate."

This theme was in alignment with research findings supporting P1,2,3 and P5. No support was found for P4.

\section{Final Theme 6: Leadership Style of the Boss}

The leadership style of the boss overlapped with theme 5 , in which adjuncts preferred to work for a servant leader. This theme means how adjunct faculty deans, managers, and supervisors lead or manage them. Most of the participants stated transformational, transactional, and servant leaders were the type of boss would allow them to remain in their roles as an adjunct faculty. Transformation, transactional, and servant leaders were most commonly mentioned. Transformational leaders are inspirational, building confidence in subordinates in an organization, which, in turn, leads to improved operational success (Anderson, 2017). Thus, transformational leaders employ the process of inspiration as a means of increasing optimism and enthusiasm among organizational subordinates. The transformational leader creates a heightened sense of awareness among subordinates about the problems requiring a solution for the organization to succeed (Konorti \& Eng, 2008).

The following interview response is representative of this theme from the interview questions.

R6 - "Transactional, transformational, those are great, I mean everyone wants to be motivated, everyone wants to be stimulated by some sort of recognition and award system, but at the end of the day, I think you really need to have a touch of everything, to be an effective leader truly. Servant leadership in collaborative settings is good for all of us."

R10 - "A lot of my examples will be involving my dean, but I think so much of him as a professor, and as a person that has been in law enforcement, has gotten his Doctorate Degree, and he's very passionate."

This theme was in alignment with research findings and supported P1, 2, 3, and 5.

\section{CONCLUSIONS}

The focus of this qualitative phenomenological study was to interview a purposeful sample of adjunct faculty in HLI. Through interviews with open-ended questions, participants shared lived experiences and perspectives relating to factors affecting decisions to remain or leave higher learning institutions. Data were analyzed to find themes using NVivo software, an electronic coding tool. Exploring the ideas and lived experiences of the participants in their role as adjunct faculty may supply data leaders can use to influence retention. 
The conclusions drawn from the study provide added insight regarding satisfaction and retention. We ascertain adjunct faculty make note of administration and faculty interaction with them and garner perceptions of respect and inclusions in initiatives. Leadership style in one factor influencing satisfaction and retention. Research findings revealed some job challenges as it relates to final theme 1; the number of students will negatively affect their decision to remain in their role. The theme directly aligned with research findings. Low levels of job satisfaction among adjunct faculty are related to job challenges, stress, long working hours, course overload, and feelings of isolation among adjunct faculty, which results in higher turnover rates. Theme 5, work for a servant leader, the participants said or implied the servant leader is ideal. Little research has been conducted in this area. This theme was in alignment with the research findings. A servant leader proves high ethical standards as well as emphasizes the importance of empowering others, developing trust, and enhancing the growth of others.

The theme leadership style of the boss referred to how deans, managers, and supervisors lead or manage adjunct faculty. The majority of the participants stated transformational, transactional, and servant leaders were boss types that would allow them to remain in their roles as an adjunct professor - the leadership style of the boss overlapped with theme 5. Transformational, transactional, and servant leaders were most commonly mentioned. Transformational leaders are inspirational, building confidence in subordinates in an organization, which, in turn, leads to the improved success of operations. Thus, transformational leaders employ the process of inspiration as a means of increasing optimism and enthusiasm among organizational subordinates. The transformational leader creates a heightened sense of awareness among subordinates about the problems requiring a solution for the organization to succeed. This theme was in alignment with research findings.

The research question that guided the study was: What factors influence the retention rate of adjunct professors in a higher learning institution? Research results addressed this question augmented with additional areas for research. Table 3 provides a summary of findings.

TABLE 3

SUMMARY OF RESEARCH FINDINGS

\begin{tabular}{|l|l|l|}
\hline Propositions & Emergent Theme & $\begin{array}{l}\text { Supported by } \\
\text { Previous Research } \\
\text { Findings }\end{array}$ \\
\hline $\begin{array}{l}\text { P1: A leader's (e.g., dean, chairs, and } \\
\text { managers) leadership style affect } \\
\text { retention of adjunct faculty. }\end{array}$ & $\begin{array}{l}\text { Theme 5: Work for a Servant Leader } \\
\text { Theme 6: Leadership Style of the } \\
\text { Boss }\end{array}$ & Support \\
\hline $\begin{array}{l}\text { P2: Transformational leadership will } \\
\text { be positively related to adjunct faculty } \\
\text { satisfaction and retention. }\end{array}$ & $\begin{array}{l}\text { Theme 5: Work for a Servant Leader } \\
\text { Theme 6: Leadership Style of the } \\
\text { Boss }\end{array}$ & Support \\
\hline $\begin{array}{l}\text { P3: Transactional will be positively } \\
\text { related to adjunct faculty satisfaction } \\
\text { and retention. }\end{array}$ & $\begin{array}{l}\text { Theme 5: Work for a Servant Leader } \\
\text { Theme 6: Leadership Style of the } \\
\text { Boss }\end{array}$ & Support \\
\hline $\begin{array}{l}\text { P4: Autocratic/democratic leadership } \\
\text { will be negatively related to adjunct } \\
\text { faculty satisfaction. }\end{array}$ & $\begin{array}{l}\text { Theme 5: Work for a Servant Leader } \\
\text { Theme 6: Leadership Style of the } \\
\text { Boss }\end{array}$ & No support \\
\hline $\begin{array}{l}\text { P5: Servant leadership will be } \\
\text { positively to adjunct faculty retention. }\end{array}$ & $\begin{array}{l}\text { Theme 5: Work for a Servant Leader } \\
\text { Theme 6: Leadership Style of the } \\
\text { Boss }\end{array}$ & Support \\
\hline $\begin{array}{l}\text { P6: Participation in university and } \\
\text { college initiatives will be positively } \\
\text { associated with adjunct faculty } \\
\text { retention. }\end{array}$ & No Emergent Theme & No Support \\
\hline
\end{tabular}




\begin{tabular}{|l|l|l|}
\hline $\begin{array}{l}\text { P7: Adjunct faculty job satisfaction } \\
\text { with be positively associated with } \\
\text { enhanced relationships with faculty } \\
\text { and students. }\end{array}$ & No Emergent Theme & No Support \\
\hline $\begin{array}{l}\text { P8: Participation in university and } \\
\text { college initiatives will be positively } \\
\text { associated with high quality teaching } \\
\text { among adjunct faculty. }\end{array}$ & No Emergent Theme & No Support \\
\hline $\begin{array}{l}\text { P9: Professional growth will not be } \\
\text { associated with adjunct faculty } \\
\text { retention. }\end{array}$ & Theme 1: Career Direction & $\begin{array}{l}\text { No support. Requires } \\
\text { additional research. }\end{array}$ \\
\hline $\begin{array}{l}\text { P10: The reputation of higher learning } \\
\text { institutions will have no effect on } \\
\text { adjunct faculty satisfaction and } \\
\text { retention. }\end{array}$ & $\begin{array}{l}\text { Theme 3: Satisfaction with the } \\
\text { College }\end{array}$ & $\begin{array}{l}\text { Not supported. } \\
\text { Requires additional } \\
\text { research. }\end{array}$ \\
\hline $\begin{array}{l}\text { P11: Adjunct faculty salary affects } \\
\text { retention. }\end{array}$ & $\begin{array}{l}\text { Theme 4: Enjoyment of Higher } \\
\text { Education }\end{array}$ & Supported \\
\hline $\begin{array}{l}\text { P12: Adjunct faculty course load } \\
\text { affects retention. }\end{array}$ & $\begin{array}{l}\text { Theme 3: Number of Students in the } \\
\text { Class }\end{array}$ & Support \\
\hline $\begin{array}{l}\text { P13: Adjunct faculty benefits (or lack } \\
\text { of benefits) influence retention. }\end{array}$ & $\begin{array}{l}\text { Theme 4: Enjoyment of Higher } \\
\text { Education }\end{array}$ & Support \\
\hline
\end{tabular}

\section{IMPLICATIONS FOR PRACTICE}

The problem addressed in this study is the satisfaction and retention of adjunct faculty in HLI with respect to why they choose to leave or stay in their current positions. Researchers agree there is a growing use of adjunct professors over full-time, tenured, and tenure-track professors. Earlier research showed there is a need for qualitative research regarding retention (Kuvakas, 2018), as little research has been done in this area. All participants in the study communicated why they are either choosing to leave or stay in their current role. Most participants were content in their roles and will remain with the institution as long as they are still enjoying higher education with appropriate course loads and feel respected and part of the university. Their ideal type of leader is some combination of a servant leader, transformational or transactional. As many colleges and universities are transitioning to the online format due to an advancing technologically savvy society, these type of leaders were being deemed as a crucial factor. With the growth of online formatting, leadership style may be essential in the overall effectiveness of the institutions.

\section{RECOMMENDATIONS FOR FUTURE RESEARCH}

Continued research on the retention of adjunct faculty is necessary as their contribution to institutional effectiveness, the growing number of institutions employing them, and the anticipated decrease in numbers due to dissatisfaction and retirement. Insufficient research exists, although research on HLI recognizes the importance of retaining experienced adjunct faculty members. Therefore, future research is needed using qualitative studies and quantitative designs. The researchers have several recommendations for future research based on this investigation.

Market research should determine if the income derived from adjunct pay is the primary means of support. Faculty members who rely heavily on adjunct pay may have different satisfaction/dissatisfaction levels versus those faculties who are teaching as a means of giving back to others or do not rely heavily on pay as a motivator. We are in the era of a gig economy. It would be interesting to investigate if teaching is viewed as a side job and what variables determine student, faculty, and HLI success. Thus intrinsic and extrinsic motivators regarding pay are worth investigating. 
Qualitative research should expand the participant base to include for-profit and not-for-profit as well as public and private institutions using a phenomenological design to garner differences between them. A larger participant sample closer to 25 might also yield undetected differences in satisfaction. In addition, consideration should be given to interviewing participants with 1 to 3 years and 5-9 years of experience, which serve to determine satisfaction differences and offers an opportunity to address dissatisfaction early. Faculty with 10+ experience may have found ways to circumvent dissatisfaction or may teach with a give back to society rationale or other intrinsic variables.

Adjunct faculty satisfaction and retention may differ greatly based on course load, professional training, career growth, and inclusion in a university, college, and department affairs. The term adjunct faculty includes part-time, non-permanent, and contract faculty. Future research should gather data and replicate the study, including full-time faculty only as study participants. In addition, a new study utilizing both adjuncts and full-time faculty is recommended. We understand the benefits of life-long learning. It would be valuable to see how professional training if provided, affects satisfaction and retention in HLI that provide such as resource. It would be beneficial to tease out the importance of adjunct faculty satisfaction and retention base on interactions with managers, department faculty, deans, chairs, and administrations. The researchers believe a quantitative study using various leadership styles is warranted. Focus groups might garner more insights and offer an alternative research method. Three focus groups per region might capture potential regional variations using the same focus as previously mentioned.

It is the hope of the authors that this research sparks interest and future investigations into the factors contributing to adjunct faculty satisfaction and retention in HLI.

\section{REFERENCES}

Abrahamson, E., Berkowitz, H., \& Dumez, H. (2016, January 11). A more relevant approach to relevance in management studies: An essay on performativity. Academy of Management Review, 41(2), 367-381. https://doi.org/10.5465/amr.2015.0205

Al-Smadi, M.S., \& Qbian, Y.M. (2015). Assessment of job satisfaction among faculty members and its relationship with some variables in Najran University. Journal of Education and Practice, 6(35), $117-123$.

Alonderiene, R., \& Majauskaite, M. (2016). Leadership style and job satisfaction in higher education institutions. International Journal of Educational Management, 30(1), 140-164. https://doi.org/10.1108/IJEM-08-2014-0106

Adjunct Action/SEIU. (2014). Crisis at the boiling point: A documentary look at adjunct workplace abuse and recommendations for federal policy change [Issue brief]. Retrieved from http://adjunctaction.org/wp-content/uploads/2014/11/Crisis-at-the-Boiling-Point_SEIU_Report1114.pdf

American Association of University Professors [AAUP]. (2013). Statement on the Affordable Care Act and part-time faculty positions. Retrieved from https://www.aaup.org /news/affordable-care-actand-part-time-faculty

American Association of University Professors [AAUP]. (2018). Data snapshot: Adjunct faculty in U.S. higher ed. Retrieved from https://www.aaup.org /news/data-snapshot-adjunct-faculty-us-highered\#.XI60FdVKipo

American Association of University Professors [AAUP]. (2019). The annual report on the economic status of the profession, 2018-19. 2019 Bulletin, pp. 61-84. Retrieved from https://www.aaup.org/report/annual-report-economic-status-profession-2018-19

Amos, P.M., Acquah, S., Antwi, T., \& Adzifome, N.S. (2015). A comparative study of factors influencing male and female lecturers' job satisfaction in Ghanaian higher education. Journal of Education and Practice, 6(4), 1-10.

Amzat, I.H., \& Idris, D.A. (2012). Structural equation models of management and structural equation models of management and decision-making styles with job satisfaction of academic staff in 
Malaysian Research University. International Journal of Educational Management, 26(7), 616645. https://doi.org/10.1108/09513541211263700

Anderson, M. (2017). Transformational leadership in education: A review of existing literature. International Social Science Review, 93(1), 1-13. Retrieved from https://digitalcommons.northgeorgia.edu/issr/vol93/iss1/4/

Asmawi, A., Zakaria, S., \& Wei, C.C. (2013). Understanding transformational leadership and R\&D culture in Malaysian universities. Innovation: Management, Policy, \& Practice, 15, 287-304. https://doi.org/10.5172/imp.2013.15.3.287

Avolio, B.J., \& Bass, B.M. (2004). Multifactor leadership questionnaire manual. Palo Alto, CA: Mind \& Garden.

Aydin, A., Sarier, Y., \& Uysal, S. (2013). The effect of school principals' leadership styles on teachers' organizational commitment and job satisfaction. Educational Sciences: Theory and Practice, $13(2), 806-811$.

Barnett, D.E. (2017). The effect of leadership on job satisfaction of online adjunct faculty at a for-profit university (Doctoral dissertation). ProQuest Abstracts and Dissertations. (UMI No. 10639231).

Barrick, M.R., Thurgood, G.R., Smith, T.A., \& Courtright, S.H. (2015). Collective organizational engagement: Linking motivational antecedents, strategic implementation, and firm performance. Academy of Management Journal, 58(1), 111-135. https://doi.org/10.5465/amj.2013.0227

Bass, B.M. (1990). Bass and Stogdill's handbook of leadership: Theory, research, and managerial applications (3rd ed.). New York, NY: Free Press.

Bass, B.M. (1994). Transformational leadership development: Manual for the Multifactor Leadership Questionnaire. Palo Alto, CA: Consulting Psychologist Press.

Bass, B.M., \& Avolio, B.J. (2008). Developing potential across a full range of leadership. Retrieved from http://www.ebookstore.tandf.co.uk

Bass, B.M., Avolio, B.J., Jung, D.I., \& Berson, Y. (2003). Predicting unit performance by assessing transformational and transactional leadership. Journal of Applied Psychology, 88(2), 207-218. https://doi.org/10.1037/0021-9010.88.2.207

Bass, B.M., \& Riggio, R.E. (2006). Transformational leadership. Mahwah, NJ: Erlbaum.

Bateh, J., \& Heyliger, W. (2014). Academic administrator leadership styles and the impact on faculty job satisfaction. Journal of Leadership Education, 13(3), 34-49. https://doi.org/10.12806/v13/i3/rf3

Bateman, T.S., \& Snell, S.A. (2009). Management: Leading \& collaborating in a competitive world (8th ed.). New York, NY: McGraw-Hill.

Bayram, H., \& Dinc, S. (2015). Role of transformational leadership on employee's job satisfaction: The case of private universities in Bosnia and Herzegovina. European Researcher, 93(4), 270-281. https://doi.org/10.13187/er.2015.93.270

Bedford, L., \& Miller, H. (2013). All adjuncts are not created equal: An exploratory study of teaching and professional needs of online adjuncts. Online Journal of Distance Learning Administration, 16(1), 1-16. Retrieved from http://www.westga.edu/ distance/ojdla/spring161/bedford_miller.html

Betts, K.S., \& Sikorski, B. (2008, Spring). Financial bottom line: Estimating the cost of faculty/adjunct turnover and attrition for online programs. Online Journal of Distance Learning Administration, $X I(\mathrm{I})$.

Bholane, K.P., \& Suryawanshi, J.R. (2015). A study of job satisfaction of university teachers in Maharashtra state. Management Today, 5(4), 192-195. https://doi.org/10.11127/gmt.2015.12.07

Blumenstyk, G. (2015). American higher education in crisis? What everyone needs to know. New York, NY: Oxford University Press.

Bockerman, P., \& Ilmakunnas, P. (2012). The job satisfaction-productivity nexus: A study using matched survey and register data. Industrial and Labour Relations Review, 65(2), 244-262. https://doi.org/10.2139/ssrn.1626126

Caruth, G.D., \& Caruth, D.L. (2013, November 15). Adjunct faculty: Who are these unsung heroes of academe? Current Issues in Education, 16(3), 1-11. 
Charmaz, K. (2006). Constructing grounded theory. Thousand Oaks, CA: Sage.

Chaudhry, A.Q., \& Javed, H. (2012). Impact of transactional and laissez-faire leadership style of motivation. International Journal of Business and Social Science, 3(7), 258-264.

Chen, Z., Zhu, J., \& Zhou, M. (2015). How does a servant leader fuel the service fire? A multilevel model of servant leadership, individual self-identity, group competition climate, and customer service performance. Journal of Applied Psychology, 100(2), 511-521. https://doi.org/10.1037/a0038036.supp

Chong, V.K., \& Monroe, G.S. (2013). The impact of the antecedents and consequences of job burnout on junior accountants' turnover intentions: A structural equation modeling approach. Accounting and Finance, 55, 105-132. https://doi.org/10.1111/acfi.12049

Choudhary, A.I., Akhtar, S.A., \& Zaheer, A. (2013). Impact of transformational and servant leadership on organizational performance: A comparative analysis. Journal of Business Ethics, 116, 433-440. https://doi.org/10.1007/s10551-012-1470-8

Christensen, C. (2008). The employment of part-time faculty at community colleges. New Directions for Higher Education, 143, 29-36. https://doi.org/10.1002/he.310

Coalition on the Academic Workforce [CAW]. (2013). A portrait of part-time faculty members: A summary of findings on part-time faculty respondents, June 2012. The Coalition on the Academic Workforce.org. Retrieved from http://www.academicworkforce.org/CAW_portrait_2012.pdf

Creswell, J.W. (2017). Research design: Qualitative, quantitative, and mixed methods approaches (5th ed.). Thousand Oaks, CA: Sage.

Creswell, J.W., \& Creswell, J.D. (2018). Research design: Qualitative, quantitative, and mixed methods approaches (5th ed.). Thousand Oaks, CA: Sage.

Curtis, J.W., \& Thornton, S. (2013, March-April). Here's the news: The annual report on the economic status of the profession, 2012-2013. Academe, 89(2), 21-103. Retrieved from http://aaup.org/

Daft, R.L. (2008). The leadership experiences. Mason, OH: South-Western Cengage Learning.

Daft, R.L. (2015). Organization theory and design (12th ed.). Boston, MA: Cengage Learning.

Deluga, R.J. (1990). The effects of transformational, transactional, and laissez-faire leadership characteristics on subordinate influencing behavior. Basic \& Applied Social Psychology, 11(2), 191-203.

Dias, M.A., \& Borges, R.S. (2017). Performance and leadership style: When do leaders and followers disagree? Mackenzie Management Review, 18, 104-129. https://doi.org/10.1590/1678-69712017

Eagan, M.K., Jaeger, A.J., \& Grantham, A. (2015). Supporting the academic majority: Policies and practices related to part-time faculty's job satisfaction. The Journal of Higher Education, 86(3), 448-481. https://doi.org/10.1353/jhe.2015.0012

Elder, S.J., \& Ryan, L.A. (2016). Work factors of importance to adjunct nursing faculty. Journal of Nursing Education, 55(5), 245-251.

Fabricant, M. (2014, Spring). Occupy higher education: Building adjunct faculty power. AFT on Campus, pp. 9-12.

Focht, A., \& Ponton, M. (2015). Identifying primary characteristics of servant leadership: Delphi Study. International Journal of Leadership Studies, 9(1), 44-61.

Francis, U.C. (2017). Transformational and transactional leadership styles among leaders of administrative ministries in Lagos, Nigeria. IFE PsychologIA, 25(2), 151-164. Retrieved from https://www.ajol.info/index.php/ifep/article/view/162265

Nelson, G., Monson, M.J., \& Adibifar, K. (2020). The gig economy comes to academia: Job satisfaction among adjunct faculty. Cogent Education, 7(1), 1786338. DOI:10.1080/2331186X.2020.1786338

Gill, A., Sharma, S.P., Mathur, N., \& Bhutani, S. (2012). The effects of job satisfaction and work experience on employee-desire for empowerment: A comparative study in Canada and India. International Journal of Management, 29(1), 190-200.

Glew, D.J., O'Leary-Kelly, A.M., Griffin, R., \& Van Fleet, D.D. (1995). Participation in organizations: A preview of the issues and the proposed framework for future analysis. Journal of Management, 21(3), 395-421. https://doi.org/10.1016/0149-2063(95)90014-4 
Government Accountability Office [GAO]. (2018). Adjunct workforce: Size, characteristics, compensation, and work experiences of adjunct and other non-tenure-track faculty. Report to Congressional Requesters, October 2017, GAO-18-49, 1-106. Washington, DC: United States Government Accountability Office.

Greenleaf, R.K. (1977). Servant Leadership: A journey into the nature of legitimate power and greatness. Mahwah, NJ: Paulist Press.

Guthrie, K.M. (2019, April). Challenges to higher education's most essential purposes. ITHAKA.org. https://doi.org/10.18665/sr.311221

Hauserman, C.P., \& Stick, S.L. (2013). The leadership teachers want from principals: Transformational. Canadian Journal of Education, 36(3), 184-203. Retrieved from https://www.jstor.org/stable/canajeducrevucan.36.3.184

Haynie, D. (2012). Increasing use of adjuncts sparks worries. Community College Week, 25, 8-9. Retrieved from http://ccweek.com/article-3085-academic-kickoff-2012:-increasing-use-ofadjuncts-sparks-worries.html

Hijazi, S., Kasim, A.L., \& Saud, Y. (2016). Leadership styles and their relationship with the private university employees' job satisfaction in United Arab Emirates. Journal of Public Administration and Governance, 6(4), 110-124. https://doi.org/10.5296/jpag.v6i4.10347

Hoeller, K. (2014). The academic labor system of faculty apartheid. In K. Hoeller (Ed.), Equality for adjunct faculty: Overcoming the two-tier system (pp. 116-155). Nashville, TN: Vanderbilt University.

House Committee on Education and the Workforce on Education and the Workforce. (2015). The just-intime professor [Staff report]. Retrieved from

http://democrats.edworkforce.house.gov/sites/democrats.edworkforce.house.gov/files/documents/ 1.24.14-AdjunctEforumReport.pdf

Hoy, W.K. (2009). School effectiveness index (SE-Index). Retrieved from www.waynekhoy.com/schooleffectiveness/

Hoy, W.K., \& Ferguson, J. (1985). A theoretical framework and exploration of organizational effectiveness. Educational Administration Quarterly, 21(2), 117-134.

Hoy, W.K., \& Miskel, C.G. (2012). Educational administration: Theory, research, and practice (9th ed.). New York, NY: McGraw-Hill.

Johnson, H. (2015). California's future: Higher education. Journal of Graduate Medical Education, pp. 13. https://doi.org/10.4300/JGME-D-11-00307.1

Kaplan, H.C., Brady, P.W., Dritz, M.C., Hooper, D.K., Linam, W.M., Froehle, C.M., \& Margolis, P. (2010). The influence of context on quality improvement success in health care: A systematic review of the literature. Milbank Quarterly, 88(4), 550-559. https://doi.org/10.1111/j.14680009.2010.00611.x

Khan, N. (2017). Adaptive or transactional leadership in current higher education: A brief comparison. International Review of Research in Open \& Distance Learning, 18(3), 178-183. https://doi.org/10.19173/irrodl.v18i3.3294

Klenke, K. (2007). Authentic leadership: A self, leader, and spiritual identity. International Journal of Leadership Studies, 3(1), 68-97.

Konorti, E., \& Eng, P. (2008). The 3D transformational leadership model. Journal of the Academy of American Business, 14(1), 10-20.

Kouzes, J., \& Posner, B. (2002). The leadership challenge (3rd ed.). San Francisco, CA: Jossey-Bass.

Kuipers, B.S., Higgs, M., Kickert, W., Tummers, L., Grandia, J., \& van de Voet, J. (2014). The management of change in public organizations: A literature review. Public Administration, 92(1), 1-20. https://doi.org/10.1111/padm.12040

Küpers, W. (2007). Perspectives in integrating leadership and followership. International Journal of Leadership Studies, 2(3), 194-221.

Kuvakas, K. (2018). Examining the factors that impact adjunct faculty retention in private non-profit universities (Doctoral dissertation). ProQuest Abstracts and Dissertations. (UMI No. 10792747). 
Lamm, A.J., Lamm, K.W., Rodriguez, M.T., \& Owens, C.T. (2016). Examining leadership style influence on engagement in a national change process: Implications for leadership education. Journal of Leadership Education, 15, 1-14. https://doi.org/1012806/V15/I4/R1

Larsson, M., Magnusson, L., \& Ullenhag, K. (2014, January). Scholarship in business history. Taylor \& Francis Journals, 56(1), 104.

Leedy, P.D., \& Ormrod, J.E. (2019). Practical research: Planning and design (12th ed.). Upper Saddle River, NJ: Pearson.

Lewin, T. (2013, April 8). Gap widens for faculty at colleges, report finds. New York Times. Retrieved from www.nytimes.com

Marlier, A. (2014). An examination of the psychological contracts of adjunct faculty teaching at urban, proprietary colleges. (Doctoral dissertation). Available from ProQuest Dissertations and Theses database.

Maxwell, J. (1996). Qualitative research design: An interactive approach. Thousand Oaks, CA: Sage.

McMillan, J.H., \& Schumacher, S. (2010). Research in education: Evidence-based inquiry (7th ed.). Upper Saddle River, NJ: Pearson Education.

McNeff, M.E., \& Irving, J.A. (2017). Job satisfaction and the priority of valuing people: A case study of servant leadership practice in a network of family-owned companies. SAGE Open, 7(1), 1-8. https://doi.org/10.1177/2158244016686813

Miles, M.B., \& Huberman, A.M. (1994). Qualitative analysis: An expanded sourcebook (2nd ed.). Thousand Oaks, CA: Sage.

Miller, W. (2018). Institutional analytics, effectiveness, and strategic planning. Retrieved from https://www.campusintelligence.com/2018/03/05/3-steps-closer-to-a-more-effective-institution/

Moran, P.A. (2014). The Affordable Care Act: Focus on adjunct faculty. Retrieved from http://www.natlawreview.com/article/affordable-care-act-focus-adjunct-faculty

Mott, P. (1972). The characteristics of effective organizations. New York, NY: Harper \& Row.

Moynihan, D.P., Pandey, S.K., \& Wright, B.E. (2012). Setting the table: How transformational leadership fosters performance information use. Journal of Public Administration Research \& Theory, 22(1), 143-164. https://doi.org/10.1093/jopart/mur024

Murray, D.S. (2019, February 12). The precarious new faculty majority: Communication and instruction research and adjunct labor in higher education. Communication Education, 68(2), 235-245. https://doi.org/10.1080/03634523.2019.1568512

Northouse, P. (2013). Leadership: Theory and practice (6th ed.). Los Angeles, CA: Sage.

Olsen, O.K., Eid, J., \& Larsson, G. (2010). Leadership and ethical justice behavior in a high moral intensity operational context. Military Psychology, 22(Supplement 1), 137-156.

Omar, W.A., \& Hussin, F. (2013). Transformational leadership style and job satisfaction relationship: A study of structural equation modeling (SEM). International Journal of Academic Research in Business and Social Sciences, 3(2), 346-365.

Pan, B., Shen, X., Liu, L., Yang, Y., \& Wang, L. (2015). Factors associated with job satisfaction among university teachers in northeastern region of China: A cross-sectional study. International Journal of Environmental Research and Public Health, 12(10), 12761-12775.

Pandey, S., Wright, B., \& Moynihan, D. (2012). Pulling the levers: Transformational Leadership, public service motivation, and mission valence. Public Administration Review, 72(2), 206-215. https://www.jstor.org/stable/41433294

Parris, D.L., \& Peachey, J.W. (2013). A systematic literature review of servant leadership theory in organizational contexts. Journal of Business Ethics, 113(3), 377-393. https://doi.org/10.1007/s10551-012-1322-6

Patten, M.L. (2012). Understanding research methods (8th ed.). Glendale, CA: Pyrczak.

Patton, M.Q. (2002). Qualitative research and evaluation methods (3rd ed.). Los Angeles, CA: Sage.

Pearch, W.J., \& Marutz, L. (2005). Retention of adjunct faculty in community colleges. Community College Enterprise, 11(1), 29-44. 
Perry, S.K. (2000). A comparison of superintendent personality profiles with middle school principals' and curriculum directors perceived organizational effectiveness. (Doctoral Dissertation). The University of Georgia. ProQuest Dissertations. (UMI No. 9984189).

Powell, B.A., Gilleland, D.S., \& Pearson, L.C. (2012). Expenditures, efficiency, and effectiveness in U.S. Undergraduate Higher Education: A National Benchmark Model. The Journal of Higher Education, 83(1), 102-127. https://doi.org/10.1080/00221546.2012.11777236

Razak, N.A., \& Hamidon, N.I. (2015). Effects of leadership styles on technical and vocational students, UTHM. Journal of Education and Practices, 6(1), 57-60. Retrieved from http://files.eric.ed.gov/fulltext/EJ1083785.pdf

Rich, T. (2015). A worthy asset: The adjunct faculty and the influences on their job satisfaction. To Improve the Academy, 34(1-2), 156-170. https://doi.org/10.1002/tia2.20010

Sakiru, O.K., Othman, J., Silong, A.D., Kareem, S.D., Oluwafemi, A.O., \& Yusuf, G.O. (2014). Relationship between head of department leadership styles and lecturers job satisfactions in Nigerian public universities. Asian Social Science, 10(6), 138-144. https://doi.org/10.5539/ass.v10n6p138

Samad, A. (2016). Towards an understanding of the effect of leadership on employee wellbeing and organizational outcomes in Australian universities. The Journal of Developing Areas, 49(6), 441448. https://doi.org/10.1353/jda.2015.0121

Sharma, L.J.K., \& Singh, S.K. (2013). Characteristics of laissez-faire leadership style: A case study. CLEAR International Journal of Research in Commerce \& Management, 4(3), 29-31. Retrieved from http://connection.ebscohost.com/c/case-studies /119659430/characteristics-laissezfaireleadership-style-case-study

Shayne, S. (2019). An exploration of adjunct faculty experiences. (Doctoral Dissertation). ProQuest Dissertations and Theses. (UMI 13900621).

Sherman, R. (2019). The case for servant leadership. Nurse Leader, 17(2), 86-87. https://doi.org/10.1016/j.mnl.2018.12.001

Smith, B., Montango, R., \& Kuzmenko, T. (2004). Transformational and servant leadership: Content and contextual comparisons. Journal of Leadership and Organizational Studies, 10(4), 80-91. https://doi.org/10.1177/107179190401000406

Smith, J.A. (2011). Evaluating the contribution of interpretative phenomenological analysis. Health Psychology Review, 5(1), 9-27. https://doi.org/10.1080/17437199.2010.510659

Smith, J.A., \& Eatough, V. (2012). Interpretative phenomenological analysis. In G.M. Breakwell, J.A. Smith, \& D.B. Wright (Eds.), Research methods in psychology (4th ed., pp. 439-459). Thousand Oaks, CA: Sage.

Smith, P.O. (2015). Leadership in academic health centers: Transactional and transformational leadership. Journal of Clinical Psychology in Medical Settings, 22(4), 228-231. https://doi.org/10.1007/s10880-015-9441-8

Song, C., Park, K.R., \& Kang, S. (2015). Servant leadership and team performance: The mediating role of knowledge-sharing climate. Social Behavior and Personality, 43(10), 1749-1760. https://doi.org/10.2224/sbp.2015.43.10.1749

Syed, N., \& Yan, L.X. (2012). Impact of high-performance human resource management practices on employee job satisfaction: Empirical analysis. Interdisciplinary Journal of Contemporary Research Business, 4(2), 318-341.

Teachers Insurance and Annuity Association of America [TIAA]. (2016a). The shifting academic workforce: Where are the adjunct faculty? In S. Hulburt (Delta Cost Project, American Institutes for Research) \& M. McGarrah (American Institutes for Research) (Eds.), (pp. 1-27). American Institutes for Research.

Teachers Insurance and Annuity Association of America [TIAA]. (2016b). Cost savings or cost shifting? The relationship between part-time adjunct faculty and institutional spending. In S. Hulburt (Delta Cost Project, American Institutes for Research) \& M. McGarrah (American Institutes for Research) (Eds.), (pp. 1-21). American Institutes for Research. 
Thamrin, H.M. (2012). The influence of transformational leadership and organizational commitment on job satisfaction and employee performance. International Journal of Innovation, Management and Technology, 3(5), 566-572. https://doi.org/10.7763/ijimt.2012.v3.299

Trottier, T., Van Wart, M., \& Wang, X.H. (2008). Examining the nature and significance of leadership in government organizations. Public Administration Review, 68(2), 319-333. https://doi.org/10.1111/j.1540-6210.2007.00865.x

Van Dierendonck, D., Stam, D., Boersma, P., De Windt, N., \& Alkema, J. (2015). Same difference? Exploring the differential mechanisms linking servant leadership and transformational leadership to follower outcomes. The Leadership Quarterly, 25(3), 544-562. https://doi.org/10.1016/j.leaqua.2013.11.014

Van Wart, M. (2013). Administrative leadership theory: A reassessment after 10 years. Public Administration, 91(3), 521-543. https://doi.org/10.1111/padm.12017

VanScoy, A., \& Evenstad, S.B. (2015). Interpretative phenomenological analysis for LIS research. Journal of Documentation, 71(2), 338-357. https://doi.org/10.1108/JD-09-2013-0118

Walters, S.A. (2015). Adjunct retention in four-year colleges: A quantitative study (Doctoral Dissertation). ProQuest Dissertations and Thesis. (UMI No. 3684891).

Zinsser, K.L.P. (2017). Adjunct faculty: Perception of leadership styles, leadership outcomes, and organizational commitment in online and faith-based education settings (Doctoral Dissertation). ProQuest Dissertations and Thesis. (UMI No. 10634594). 